\title{
Comparison of Surface Runoff Quality between Dry and Wet Period and Characteristics of Pollutant Runoff in a Lake Watershed
}

\author{
Jae Heon Cho
}

\begin{abstract}
Numerous golf courses are being constructed in Korea lately. Along with the construction, many civil complaints are filed against destruction of environment and use of pesticides and fertilizers that are known to significantly affect the water quality of surface water near golf courses. This study analyzes the result of storm water runoff of eutrophic lake watershed in which diffuse pollution sources such as golf resort drainage and agricultural drainage are significant pollution sources. 10 storm water runoff surveys were carried out at Jangcheon Stream and a storm sewer from 2004 to 2007 and water quality was also surveyed weekly from June 2005 to August 2007 in dry seasons as well. Water quality of Flow, TP (Total phosphorus), $\mathrm{PO}_{4}-\mathrm{P}, \mathrm{TN}\left(\right.$ Total nitrogen), $\mathrm{NO}_{3}-\mathrm{N}, \mathrm{SS}$, BOD, COD were surveyed. EMCs (Event mean concentrations) of storm water runoff were higher than the mean concentration surveyed for 27 months during dry seasons in both sites. Difference between EMC and the mean concentration during dry seasons was especially large in JM (main stream of the Jangcheon) site which is directly under the influence of Golf resort. Mass-volume curve and evaluation of the first flush effect was completed by utilizing storm runoff surveys.
\end{abstract}

Index Terms-EMC, golf resort, mass-volume curve, storm water runoff.

\section{INTRODUCTION}

Youngrang Lake, the subject area of this research, is well known for its beautiful landscape and thus serves as a park for local residents. Although most of the wastewater of the residential area near this lake is treated at wastewater treatment plants, algal growth is highly active and eutrophication has been occurred during seasons with high water temperature. Currently, the main pollution sources of Youngrang Lake are Jangcheon Stream which is the largest inflow of Youngrang Lake, and storm water runoff from residential area. In upper parts of the Jangcheon, resorts with large condominiums and golf courses are operating. Hence, management of diffuse pollution loads is required for water quality management of this lake. The effects of golf courses on the surface water quality and the control methods of the diffuse pollution loads were studied by several researchers [1]-[4]. Storm water runoff was surveyed for four years,

\footnotetext{
Manuscript received December 5, 2012; revised February 15, 2013. This research was supported in part by the Basic Science Research Program through the National Research Foundation of Korea (NRF) funded by the Ministry of Education, Science and Technology (grant number 2010-0024879).

Jae Heon Cho is with the Department of Health and Environment, Kwandong University, Gangneung, Gangwondo 210-701, Korea (e-mail: jhcho@kd.ac.kr).
}

from 2004 to 2007, in order to determine the characteristics of diffuse pollution loads of Youngrang lake. With this result, pollutograph and hydrograph of each rainfall event were drawn to analyze first flush effect [5]-[8]. The effect of golf courses on storm water quality was determined by EMC analysis [9], [10].

\section{METHODS}

\section{A. Study Area and Water Quality Survey}

Lake Youngrang is a lagoon which is located on the east coast of South Korea. Its drainage area is $7.8 \mathrm{~km}^{2}$ and surface area is $1.02 \mathrm{~km}^{2}$. The map of the Youngrang watershed and sampling sites is shown in Fig. 1. Most pollution loads flowing into the Youngrang lake are from Jangcheon Stream, the largest inflow of Yongrang Lake, and the storm sewer of residential area on the south of the Lake. Most of the Jangcheon drainage area are forest and agricultural land, and a large golf resort is in the upper parts of the Jangcheon (Table I). Residential area is distributed mostly along the south side and partly on the north side of the lake. Also, a significant amount of storm water flow into the Youngrang Lake from the storm sewer outfall on the south of the lake during rainfall. Part of the golf course is located in the drainage area of this storm sewer.

Ten Rainfall events were surveyed for main stream of Jangcheon(JM) and storm sewer(SW) on the south of the Youngrang Lake from 2004 to 2007 (Table II). Sampling and flow measurements were done at 15 and 30-minute intervals for increasing flow stage and at 1 and 2 hour intervals for decreasing flow stage. TP, $\mathrm{PO}_{4}-\mathrm{P}, \mathrm{TN}, \mathrm{NO}_{3}-\mathrm{N}, \mathrm{SS}, \mathrm{BOD}$, $\mathrm{COD}$ were analyzed from the water samples. In dry seasons, water quality was surveyed weekly from June 2005 to August 2007 at JM and SW.

\section{B. Event Mean Concentrations and $M(V)$ curves}

It is not appropriate to use arithmetic mean as a representative value of time-based water quality data in a certain rainfall event. Because rainfall intensity, runoff flow and runoff quality during a rainfall event vary by time, mean water quality of a certain rainfall event needs to be calculated by weighting factor of runoff flow. The EMC was defined as mass of pollutant contained in the runoff event divided by total volume of flow in the event. The EMC was used to estimate storm water pollutant loads [11] and to investigate the existence of a seasonal first flush [12]. 

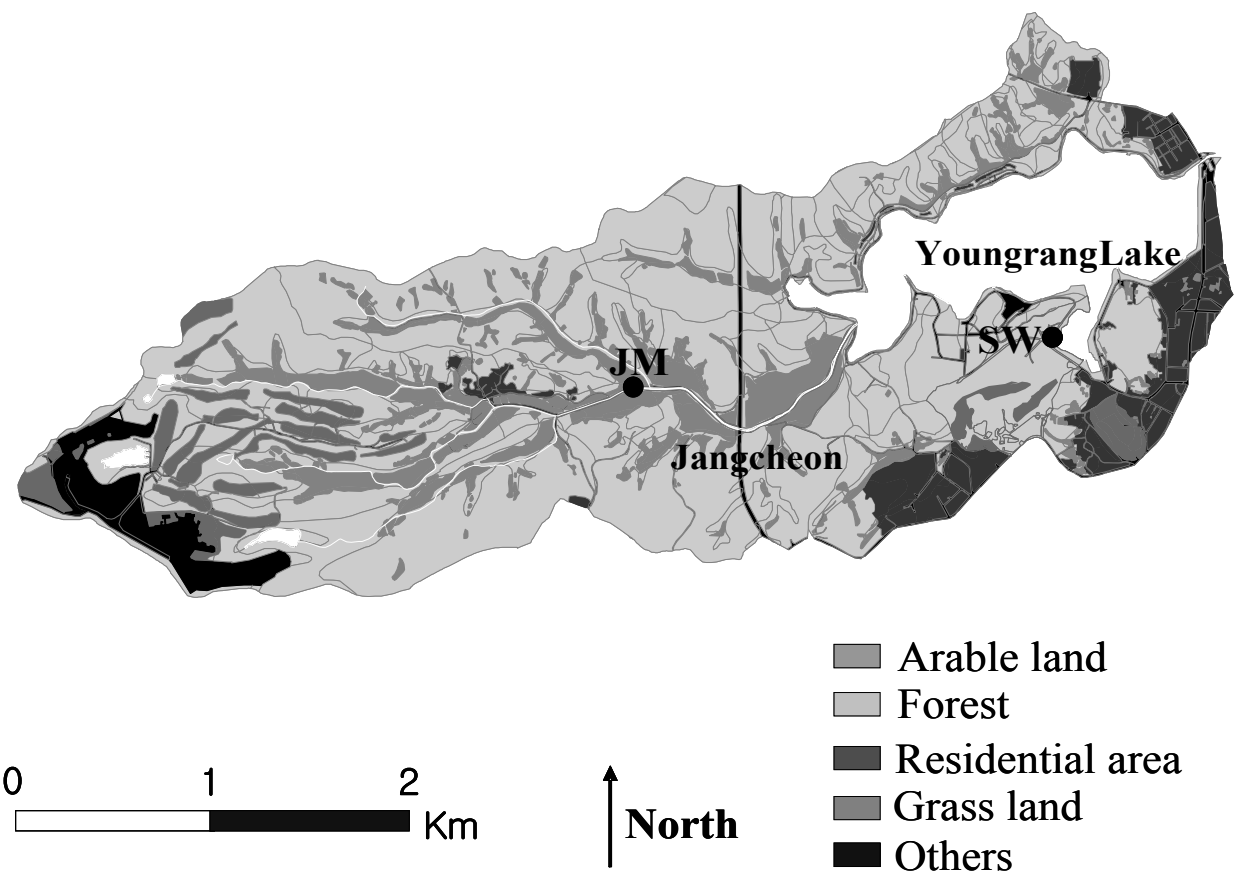

Fig. 1. The Youngrang Lake watershed and location of study sites.

TABLE I: LANDUSE OF THE JANGCHEON STREAM AND YOUNGRANG LAKE WATERSHED

\begin{tabular}{|c|c|c|c|c|c|}
\hline & & Land use $(\%$ & & & \\
\hline Catchmen & Residence & $\begin{array}{l}\text { Resort } \\
\text { and } \\
\text { golf Agric } \\
\text { course }\end{array}$ & liture Forest & $\begin{array}{c}\text { Drainage Land } \\
\text { area slope } \\
\left(\mathrm{km}^{2}\right) \quad(\%)\end{array}$ & $\begin{array}{c}\mathrm{d} \\
\text { Impervious } \\
\text { area } \%)\end{array}$ \\
\hline Jangcheol & 3.1 & 12.6 & 67.7 & 4.75 & 8.7 \\
\hline Youngrang I & 11.6 & 9.8 & 65.7 & $\begin{array}{ll}7.79 & 12.6\end{array}$ & 14.7 \\
\hline & TABLLF & E II: SURVEYE & D RAINFALL & EVENTS & \\
\hline $\begin{array}{c}\text { Rainfall } \\
\text { event }\end{array}$ & Date & $\begin{array}{l}\text { Precipitation } \\
\quad(\mathrm{mm})\end{array}$ & $\begin{array}{c}\text { Duration } \\
\text { (hr) }\end{array}$ & $\begin{array}{c}\text { Dry days } \\
\text { prior to } \\
\text { storm }\end{array}$ & $\begin{array}{l}\text { Sampling } \\
\text { site }\end{array}$ \\
\hline 04-1 & $\begin{array}{c}\text { June } 19, \\
2004\end{array}$ & 95.4 & 36 & 22 & $\mathrm{JM}$ \\
\hline $04-2$ & July 1, 2004 & 50 & 17 & 9 & $\mathrm{JM}$ \\
\hline $04-3$ & $\begin{array}{c}\text { August 1, } \\
2004\end{array}$ & 19 & 16 & 3 & $\mathrm{JM}$ \\
\hline $04-4$ & $\begin{array}{c}\text { September } \\
6,2004\end{array}$ & 90.5 & 28 & 14 & $\mathrm{JM}$ \\
\hline $05-1$ & $\begin{array}{c}\text { June } 30, \\
2005\end{array}$ & 19.6 & 5 & 3.2 & JM, SW \\
\hline $05-2$ & July 8, 2005 & 46 & 18 & 3.2 & JM, SW \\
\hline $05-3$ & $\begin{array}{c}\text { July } 28, \\
2005\end{array}$ & 29 & 12.5 & 14.7 & JM, SW \\
\hline $05-4$ & $\begin{array}{c}\text { August 24, } \\
2005\end{array}$ & 96.2 & 28.2 & 2.5 & JM, SW \\
\hline $07-1$ & $\begin{array}{c}\text { May 16, } \\
2007\end{array}$ & 48.8 & 19 & 0.83 & JM \\
\hline $07-2$ & $\begin{array}{c}\text { August 27, } \\
2007\end{array}$ & 36 & 24.8 & 1.16 & $\mathrm{JM}$ \\
\hline
\end{tabular}

\section{Results AND Discussion}

Table III indicates mean values of weekly measured water quality data from 2005 until 2007 in the dry season. Concentrations of pollutants at SW were generally higher than JM during dry seasons because golf course drainage and part of wastewater from residential area flows into site SW.

Estimated EMCs at mainstream of the Jangcheon(JM) and storm sewer(SW) are as shown in Table IV. EMCs at JM ranged from $19.6-301.7 \mathrm{mg} / \mathrm{L}$ for $\mathrm{SS}, 8.2-52.0 \mathrm{mg} / \mathrm{L}$ for COD, $1.72-6.49 \mathrm{mg} / \mathrm{L}$ for TN, $0.161-0.555 \mathrm{mg} / \mathrm{L}$ for TP. Mean values of EMCs in JM are 122.9 for SS, 26.5 for COD, 3.20 for TN and 0.304 for TP, respectively. EMCs in the SW are slightly higher than the JM. At JM, mean EMCs about all kinds of water quality parameters of storm water runoff were higher than mean water quality concentrations in the dry season. Storm water EMCs of SS, COD, TP at JM were especially higher than the mean values in the dry season. This is speculated to be the result of extensive influence of golf resort drainage and agricultural drainage. EMCs of all water quality parameters except $\mathrm{TN}$ were higher than that of mean water quality in the dry seasons at SW as well, but its difference was smaller than that of JM. For SW, difference of mean EMC and mean water quality of dry seasons is lower because the water quality itself is poor at SW during dry seasons.

TABLE III: MEAN VALUES OF WEEKLY MEASURED WATER QUALITY FROM 2005 UNTIL 2007 IN THE DRY SEASON

\begin{tabular}{cccccccccc}
\hline \hline Station & Flow & $\begin{array}{c}\mathrm{SS} \\
\left(\mathrm{m}^{3} / \mathrm{s}\right)\end{array}$ & $\begin{array}{c}\mathrm{BOD} \\
(\mathrm{mg} / \mathrm{L})\end{array}$ & $\begin{array}{c}\mathrm{COD} \\
(\mathrm{mg} / \mathrm{L})\end{array}$ & $\begin{array}{c}\mathrm{TN} \\
(\mathrm{mg} / \mathrm{L})\end{array}$ & $\begin{array}{c}\mathrm{NO}_{3}-\mathrm{N} \\
(\mathrm{mg} / \mathrm{L})\end{array}$ & $\begin{array}{c}\mathrm{TP} \\
(\mathrm{mg} / \mathrm{L})\end{array}$ & $\begin{array}{c}\mathrm{PO}-\mathrm{P} \\
(\mathrm{mg} / \mathrm{L})\end{array}$ \\
\hline $\mathrm{JM}$ & 0.112 & 6.08 & 1.97 & 9.22 & 2.13 & 1.21 & 0.063 \\
$\mathrm{SW}$ & 0.019 & 8.6 & 5.66 & 22.21 & 4.61 & 1.15 & 0.192 & 0.111 \\
\hline \hline
\end{tabular}



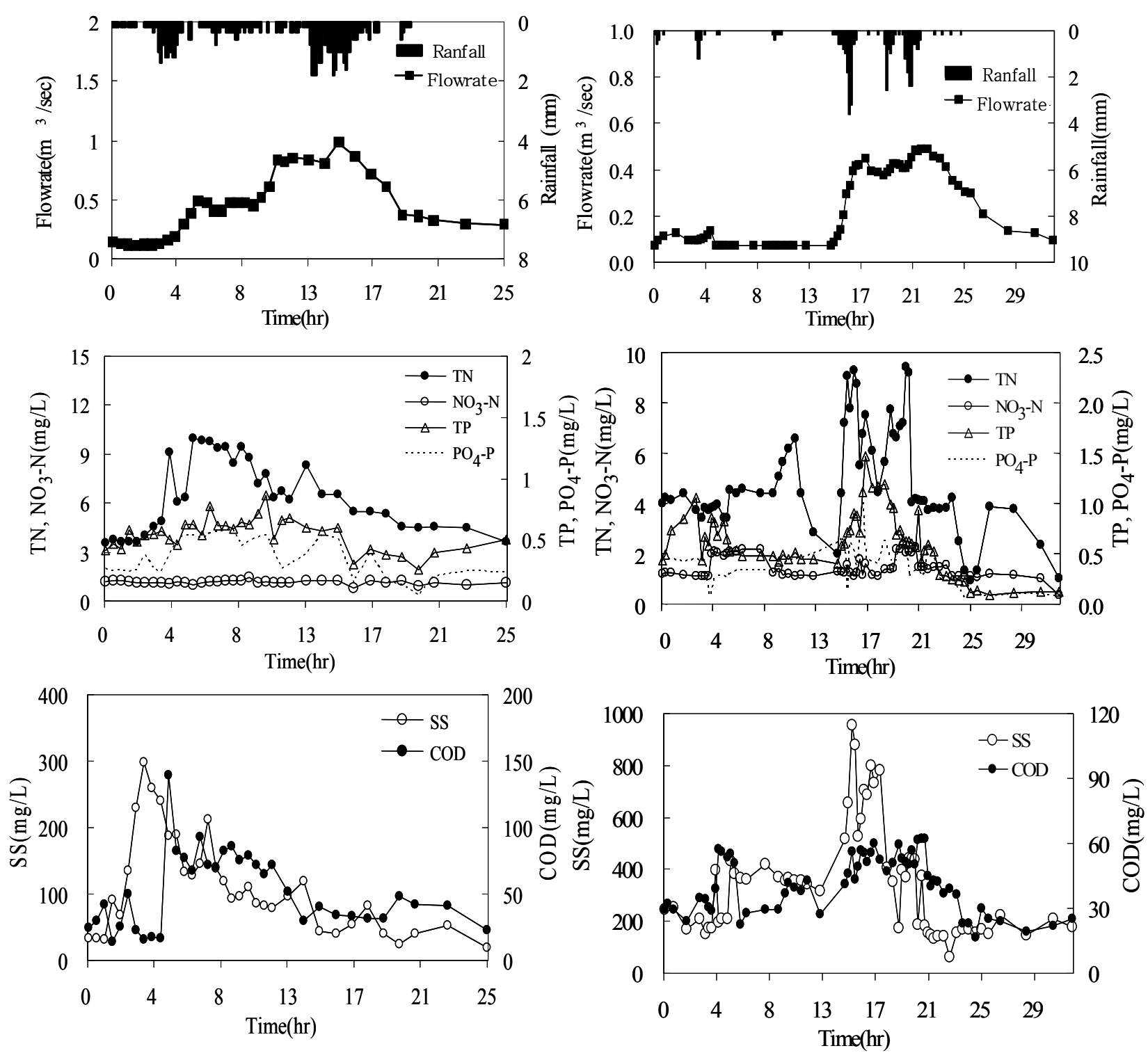

(A)

(B)

Fig. 2. Pollutographs and hydrographs for storm event 07-1(a) and 07-2(b) at site JM

TABLE IV: EVENT MEAN CONCENTRATIONS AT EACH SAMPLING STATION

\begin{tabular}{|c|c|c|c|c|c|c|c|c|}
\hline Station & $\begin{array}{l}\text { Rainfall } \\
\text { event }\end{array}$ & $\begin{array}{c}\mathrm{SS} \\
(\mathrm{mg} / \mathrm{L})\end{array}$ & $\begin{array}{c}\text { BOD } \\
(\mathrm{mg} / \mathrm{L})\end{array}$ & $\begin{array}{c}\text { COD } \\
(\mathrm{mg} / \mathrm{L})\end{array}$ & $\begin{array}{c}\mathrm{TN} \\
(\mathrm{mg} / \mathrm{L})\end{array}$ & $\begin{array}{l}\mathrm{NO}_{3}-\mathrm{N} \\
(\mathrm{mg} / \mathrm{L})\end{array}$ & $\begin{array}{c}\mathrm{TP} \\
(\mathrm{mg} / \mathrm{L})\end{array}$ & $\begin{array}{l}\mathrm{PO}_{4}-\mathrm{P} \\
(\mathrm{mg} / \mathrm{L})\end{array}$ \\
\hline \multirow{11}{*}{$\mathrm{JM}$} & $07-1$ & 89.8 & - & 52.0 & 6.490 & 1.603 & 0.526 & 0.360 \\
\hline & $07-2$ & 301.7 & - & 39.0 & 4.534 & 1.404 & 0.555 & 0.406 \\
\hline & $05-1$ & 54.1 & 4.9 & 19.6 & 1.850 & - & 0.208 & - \\
\hline & $05-2$ & 43.6 & 4.8 & 8.2 & 2.133 & - & 0.161 & - \\
\hline & $05-3$ & 19.6 & 2.6 & 21.6 & 2.705 & - & 0.229 & - \\
\hline & $05-4$ & 135.7 & 3.3 & 18.3 & 2.453 & - & 0.260 & - \\
\hline & $04-1$ & 215.1 & 3.2 & 29.8 & 4.213 & - & 0.289 & - \\
\hline & $04-2$ & 145.2 & 2.3 & 27.2 & 4.060 & - & 0.365 & - \\
\hline & 04-3 & 75.5 & 3.7 & 18.9 & 1.838 & - & 0.166 & - \\
\hline & 04-4 & 148.3 & 2.9 & 29.7 & 1.716 & - & 0.279 & - \\
\hline & mean & 122.9 & 3.4 & 26.5 & 3.199 & 1.504 & 0.304 & 0.383 \\
\hline \multirow{5}{*}{ SW } & $05-1$ & 172.2 & 9.3 & 31.5 & 2.953 & - & 0.357 & - \\
\hline & $05-2$ & 114.9 & 7.1 & 35.4 & 3.584 & - & 0.332 & - \\
\hline & $05-3$ & 144.0 & 6.1 & 34.4 & 2.530 & - & 0.635 & - \\
\hline & $05-4$ & 144.6 & 8.2 & 28.7 & 3.110 & - & 0.327 & - \\
\hline & mean & 143.9 & 7.7 & 32.5 & 3.045 & - & 0.413 & - \\
\hline
\end{tabular}



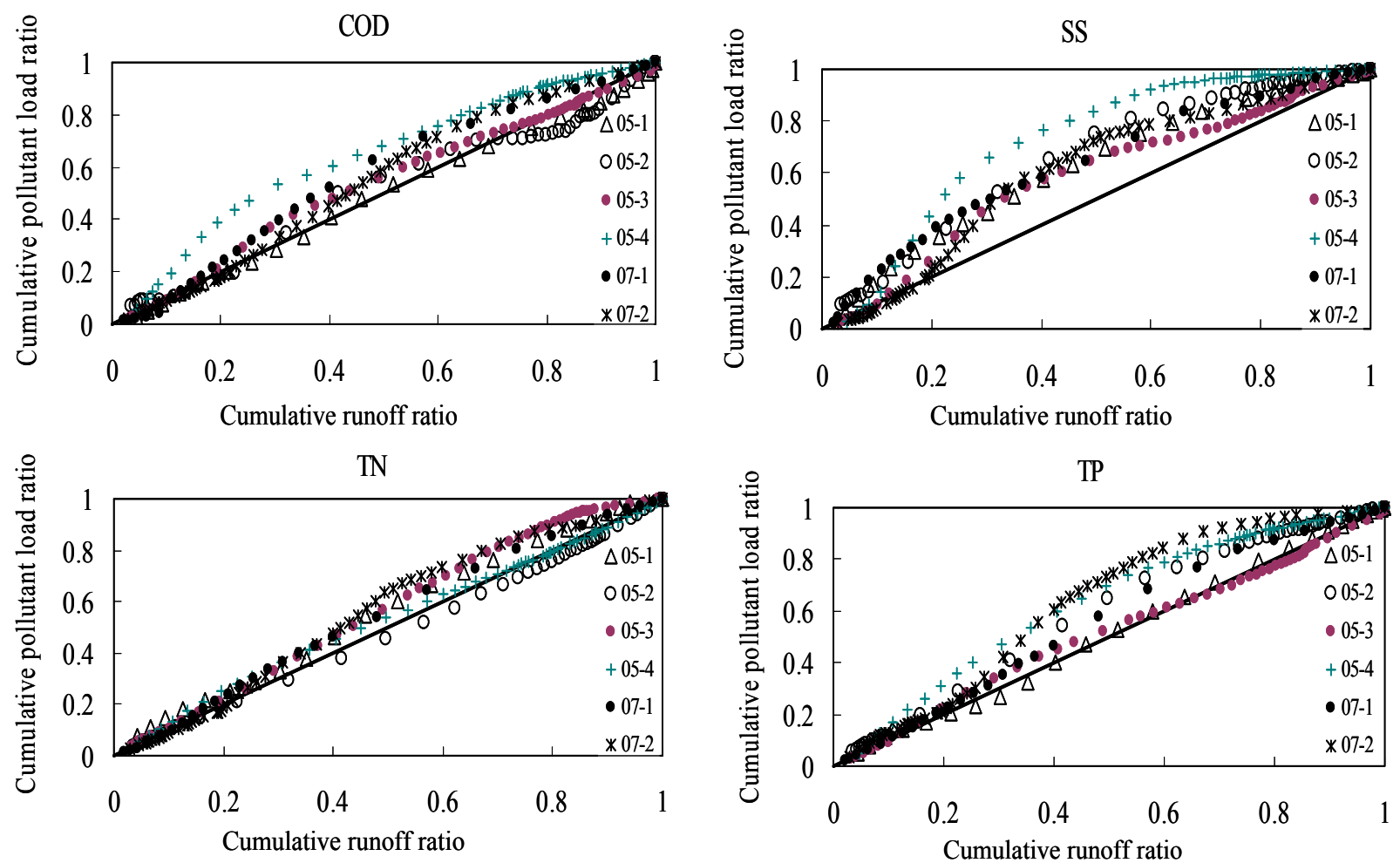

Fig. 3. Mass-volume curve at site JM

Pollutographs and hydrographs for storm event $07-1$ at site $\mathrm{JM}$ are shown in Fig. 2. As shown in the figure, the peaks of rainfall intensity and runoff flow were at the late stage of rainfall. Nevertheless, SS and COD concentrations were especially high at the initial stage of rainfall, and no significant peak was shown for other water quality parameters. Judging by this, first flush effect occurred for SS and COD for storm event 07-1 at JM. In storm event 07-02, rainfall intensity was very low and the rainfall was intermittent at the first stage of rainfall. As a significant amount of rain began, the peaks of SS and COD appeared immediately. It means a first flushing in storm event 07-2. At $\mathrm{JM}$, first flush effect was shown for SS and COD in most other surveys as well and its intensity for SS in particular was greater than that of COD. Also, first flush effect for SS and COD occurred at site SW as well, though weaker than that at site JM.

Fig. 3 shows M (V) curves at site JM. Deviation of the M (V) curve above the bisector is an indicator of first flush. Points of Mass (V) curve for SS at site JM are far from the bisector, thus relatively strong first flushing exist. Most of points of $\mathrm{M}(\mathrm{V})$ curve for COD are located above the bisector, but were closer compared to that of SS. Hence a weak first flushing occurs.

\section{CONCLUSION}

Survey results of storm water runoff of eutrophic lake watershed in which golf resort drainage is a major pollution source were analyzed. Mean EMCs about all kinds of water quality parameters of storm water runoff were higher than mean water quality concentrations in the dry season at JM. Especially, EMCs of SS, COD, TP and $\mathrm{PO}_{4}-\mathrm{P}$ were outstandingly higher than the dry season. This is speculated to be due the substantial influence of golf resort drainage and agricultural drainage. Even in the case of SW, EMCs of most water quality parameters are higher than that during the dry seasons but the difference is smaller than that of JM. In most surveys at JM, concentration of SS and COD is especially high at the initial stage of rainfall. Thus first flush effect for SS and COD was discovered at JM. and the first flush effect of SS, in particular, was more distinct than that of COD. First flush effect of SS and COD was also shown at SW, though it was less distinct than that of JM. Similarly, first flushing was also shown in $\mathrm{M}(\mathrm{V})$ curve.

\section{ACKNOWLEDGMENT}

This research was supported by the Basic Science Research Program through the National Research Foundation of Korea (NRF) funded by the Ministry of Education, Science and Technology (grant number 2010-0024879). I would also like to thank our students in the Department of Health and Environment for their assistance in sampling and analysis.

\section{REFERENCES}

[1] T. Morioka, "Three types of approaches to controlling non-point source pollution of agrochemicals from golf links in water resources management," Water Science and Technology, vol. 28, no. 3-5, pp. 549-559, 1993.

[2] J. G. Winter and P. J. Dillon, "Effects of golf course construction and operation on water chemistry of headwater streams on the Precambrian Shield," Environmental Pollution, vol. 133, pp. 243-253, 2005.

[3] S. C. Ryals, M. B. Genter, and R. B. Leidy, "Assessment of surface water quality on three Eastern North Carolina golf courses," Environmental Toxicology and Chemistry, vol. 17, no. 10, pp. 1934-1942, 1998.

[4] E. A. Kohler, V. L. Poole, Z. J. Reicher, and R. F. Turco, "Nutrient, metal, and pesticide removal during storm and nonstorm events by a constructed wetland on an urban golf course," Ecological Engineering, vol. 23, pp. 285-298, 2004. 
[5] P. B. Bedient, D. A. Harned, and W. G. Characklis, "Stormwater analysis and prediction in Houston," J. Environ. Eng. Div. ASCE, vol. 104, no. EE6, pp. 1087-1100, 1978

[6] J. L. Bertrand-Krajewski, G. Chebbo, and A. Saget, "Distribution of pollutant mass vs volume in stormwater discharge and the first flush phenomenon," Water Research, vol. 32, no. 8, pp. 2341-2356, 1998.

[7] J. H. Lee and K. W. Bang, "Characterization of urban stormwater runoff," Water Research, vol. 34, no. 6, pp. 1773-1780, 2000.

[8] V. Novotny, Water Quality: Diffuse polLution and Watershed Management, John Wiley \& Sons, Inc., New York, USA, 2003.

[9] L. H. Kim, S. O. Ko, S. Jeong, and J. Yoon, "Characteristics of watershed-off pollutants and dynamic EMCs in parking lots and bridges during a storm," Science of Total Environment, vol. 376, pp. 178-184, 2007.

[10] J. Zhaoi, B. Shan, and C. Yin, "Pollutant loads of surface runoff in Wuhan City Zoo, an urban tourist area," Journal of Environmental Sciences, vol. 19, pp. 464-468, 2007.
[11] Q. Chen, B. Shan, C. Yin, and C. Hu. "Two alternative modes for diffuse pollution control in Wuhan City Zoo," Journal of Environmental Sciences, vol. 19, pp. 1067-1073, 2007.

[12] H. Lee, S. Lau, M. Kayhanian, and M. K. Stenstrom, "Seasonal first flush phenomenon of urban stormwater discharges," Water Research, vol. 38, no. 19, pp. 4153-4163, 2004.

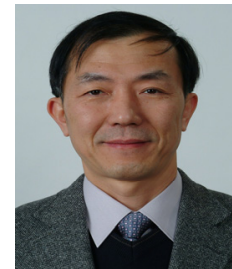

Jae Heon Cho was born on November 9, 1956 in Busan, South Korea. He received an undergraduate degree and a Ph.D. in civil engineering from Seoul National University. His main research area is water quality management and modeling. He currently is an editor of Korean Journal of Environmental Impact Assessment and a professor of Department of Health and Environment, Kwandong University in Korea. 